$\left.\begin{array}{l}\text { Sournals } \\ \text { INTERNATIONAL JOURNAL OF } \\ \text { ORGANIZATIONAL LEADERSHIP }\end{array}\right) \begin{gathered}\text { INDUSTRIAL } \\ \text { MANAGEMENT } \\ \text { INSTITUTE }\end{gathered}$

\title{
Employees' need for independence, organizational commitment, and turnover intentions: The moderating role of justice perceptions about performance appraisals
}

\author{
Burcu Birecikli ${ }^{1}$, Lütfihak Alpkan $^{2}$, Alper Ertürk ${ }^{3 *}$, Seval Aksoy ${ }^{4}$ \\ ${ }^{1}$ Postgratduate student, Dogus University \\ ${ }^{2}$ Professor, Istanbul Technical University \\ ${ }^{3}$ Professor, Düzce University \\ ${ }^{4}$ Lecturer, Dogus University
}

\begin{tabular}{l}
\hline \\
Keywords: \\
Performance Appraisals, \\
Justice Perceptions, Need \\
for Independence, Affective \\
Commitment, Turnover \\
Intentions \\
\hline Received \\
10 February 2016 \\
Received in revised form \\
14 June 2016 \\
Accepted \\
15 June 2016 \\
\hline
\end{tabular}

Correspondence

draerturk@gmail.com

\section{Abstract}

This empirical research attempts to find out whether it is possible to retain employees who possess strong need for independence and to make them committed by using fair performance appraisal systems. One hundred five white-collar employees working in three high-tech companies were participated in this study. Results showed that both perceived procedural justice and perceived distributive justice of the performance appraisals moderated the relationship between need for independence and affective commitment, as well as the relationship between need for independence and turnover intentions. As a result, the high levels of justice perceptions will lessen the strength of negative relationship between need for independence and organizational commitment and the high levels of justice perceptions will lessen the strength of positive relationship between need for independence and turnover intentions. These findings underlined the importance of justice perceptions, since they not only lead to positive attitudes and behaviors, but also mitigate the effects of the individual attitudes such as need for independence.

(C)AIMI Journals

\section{Introduction}

Employee's need for independence has been a real challenge for the employers. On one hand, this individual characteristic is an indicator of responsible, mature, and entrepreneurial human capital; but on the other hand, it is one of the key motivators to become a new rival against the present employer. Rather than autocratic management with adherence to rules, procedures, and 
norms, employees with high need for independence prefer to have control and work in unrestricted creativity-permitted working environment (Cromie, 2000). High independents prefer to be assigned to meaningful tasks on which they can demonstrate their creativity and use initiative. They become satisfied when they are offered decision making freedom and job enrichment (Orpen, 1985). Otherwise, employees with higher levels of need for independence feel that their intrapreneurial efforts are not supported or recognized; and this frustration may lead them to seek other job opportunities.

For today's competitive business world, it is important to retain qualified employees in the organization since those employees possess higher levels of job and organizational knowledge and it is so costly to replace those employees with the competent ones having high levels of skills (Ertürk \& Vurgun, 2015). Organizational climatic factors and reward systems may contribute both to the employee satisfaction and commitment (Bulut \& Alpkan, 2006). Challenging point here is that qualified employees are usually the ones who possess higher levels of need for independence and they may tend to leave their organizations if they are treated unfairly (Erdoğan, 2002). In this concern, organizational performance appraisal system in which employees' performance is measured according to performance standards and its outcomes (rewards and penalties) should be perceived by the employees. Perception about the fairness of both the decision-making processes, i.e. procedural justice (Giles, Findley \& Feild, 1997; Swiercz, Icenogle, Bryan \& Renn, 1993) and the allocations of outcomes, i.e. distributive justice (Steensma \& Visser, 2007; Swiercz et al., 1993) are used as a means for both developing employees' level of emotional attachment to the organization's goals and values, i.e. affective commitment (Fletcher \& Williams, 1996; Meyer \& Allen, 1991) and reducing employees' conscious desire to leave their organization, i.e. turnover intention (Tett \& Meyer, 1993). Hence, justice perceptions about the performance appraisals may be utilized to help firms retain their human capital especially when employees' need for independence is high. However, empirical studies on the interactions among justice perceptions, organizational attitudes, and the need for independence are surprisingly rare or even non-existent in the past literature.

In the era of knowledge economy, especially the high-tech firms suffer from high turnover rates and it becomes harder for them to keep talents in order to strengthen and maintain their competitive advantages (e.g. Chien, Lawler, \& Uen, 2010). Especially from the financial point of view, the costs of hiring and training employees are very high; the total cost of losing a qualified employee in a high-tech firm is estimated between $50 \%$ and $150 \%$ of his or her annual salary, depending on the level of individual skill and the level of the position within the organization (Von Hagel \& Miller, 2011).

Recent studies regarding the Turkish IT sector have also emphasized the high turnover rates and turnover intentions among IT professionals working in Turkish organizations in various sectors (Calışır, Gumuşsoy, \& Iskin, 2011; Kırmızı \& Deniz, 2009). Accordingly, the motivation behind this study is to test empirically the role of justice perceived by the employees to be embedded in the performance evaluation mechanisms within the context of large high-tech firms in Turkey, since larger firms evaluate the performance of their employees more frequently and formally and high-tech firms need to retain their human capital more (Grund \& Sliwka, 2009). This empirical research therefore attempts to give an insight about 
whether it is possible to retain and make employees with higher levels of need for independence committed to their organizations that use fairly perceived performance appraisals in the Turkish context. More specifically, this study attempts to investigate whether perceived justice of performance appraisal has a moderating effect on the relationship between the need for independence and two work-related attitudes, namely affective commitment and turnover intentions.

\section{The Literature Review Need for Independence}

Hisrich and Peters (1996) mention the concept of "the need for independence" as one of the most important motivators for the initiation of entrepreneurial attitudes and behaviors. Thus, employees with higher need for independence are potential entrepreneurs, i.e. potential competitors of their current organization. This trait is also highly correlated to such other entrepreneurial traits as internal locus of control, risk taking propensity, and the entrepreneurial potential (Alpkan, Keskin, \& Zehir, 2002). Steers and Braunstein (1976) demonstrated that the need for independence is negatively correlated with organizational commitment and is positively correlated with the intention to quit. In general, high independents have weak affective commitment because they prefer to have more power and authority on their work, as well as to be managerially and financially independent. They are more sensitive for external career opportunities and tend to perceive any misconduct in the human resource management policies and practices as a source of frustration with their current organization. Moreover, in case where employees feel that there is a breach of psychological contract caused by their organization, their work-related attitudes and behaviors easily begin to deteriorate (Suazo, 2009). Especially, high independents do not easily develop any emotional attachment towards the organization where they are not free both to make their own decisions and to collect the fruits of their own efforts. Therefore, employees' need for independence is a negative driver of organizational commitment and a positive one for the intention to quit.

\section{Justice Perceptions}

Shared moral values such as justice, trust, honesty, and hardworking are assumed in general to be among the drivers of internal integration of the human resources (Eren, Alpkan, \& Ergün, 2003). Especially employee perceptions about organizational justice both distributive and procedural have critical impact on employee retention (Elci, Şener, \& Alpkan, 2011). Perceptions of distributive justice depend on the comparisons employees make. Adams's (1965) equity theory states that an individual employee compares his or her own performance (input) and the rating he or she receives (output) with peers' performance and the ratings they receive. After this mental comparison, the employee decides whether the organizational performance appraisal system is fair (Erdoğan, 2002). For instance, employees' satisfaction with a pay increase is dependent on their perceptions of distributive justice (Folger \& Konovsky, 1989; Konovsky, Folger, \& Cropanzano, 1987). As a result, on the one hand, employees who get less than they feel they deserve experience unfavorable inequity and frustration. However, on the other hand, those who receive low ratings try to improve their performance if they acknowledge the fairness of the appraisal results. Otherwise, their 
subsequent performance is inclined to decline (Flint, 1999). Employees who think that the performance evaluation system in their organization is effective develop more satisfaction and commitment (Erdil, Alpkan, \& Biber, 2004). When we consider the impact of distributive justice perceptions on commitment, we can assume that employee satisfaction about the outcomes of the appraisals, especially pay satisfaction and promotion satisfaction, might lead directly to an important increase in their organizational commitment. Findings of past research have already confirmed this relationship (e.g. McFarlin \& Sweeney, 1992; Tang \& SarsfieldBaldwin, 1996).

Perceptions of procedural justice depend on the impressions employees have about the decision making process in the performance appraisal system. Employees perceive it as fair, if some or all of the following conditions are present: this system is formally, properly, and regularly executed in the organization, employees receive a politely and courteously performance feedback based on observations, evidence, and reason (Flint, 1999; Giles et al., 1997). Moreover, procedural justice perceptions positively affect employees' emotional attachment towards their organization (Levy \& Williams, 1998; Steensma \& Visser, 2007).

As for the relation of justice perceptions to the turnover intentions, there is a wellestablished negative link between turnover intention and commitment in the literature (e.g. Loi, Hang-Yue, \& Foley, 2006; Vandenberghe \& Bentein, 2009). This linkage can be attributed to the possibility that those employees who feel that they are treated unfairly both in terms of decision-making processes and distributions of outcomes in the present organization may incline to look for new job opportunities in other organizations. Empirical findings of Alexander and Ruderman (1987) and Loi et al. (2006) also confirm that both procedural justice and distributive justice exert negative effects on the intention to quit. Furthermore, when employees perceive that their performance ratings are manipulated because of raters' personal biases and intent to punish subordinates, they express reduced job satisfaction that, in turn, leads to greater intentions to quit (Poon, 2004).

\section{Moderating Role of Justice Perceptions}

Employees are sensitive to the treatment they experience within their organization and this sensitivity influences their organizational attitudes (Manville, 2008). In this concern, human resource management practices that improve employees' justice perceptions create a general understanding within the minds of the employees about the quality of work life and the general working climate of the organization. Recent research indicates that if employees feel that they work in a climate that suits their expectations in terms of fairness, morality, and intrapreneurship, then their attachment, satisfaction, motivation, and performance increase (e.g. Simard, Doucet, \& Bernard, 2005; Ruiz-Moreno, Garcia-Morales, \& Llorens-Montes, 2008; Elci \& Alpkan, 2009; Loi, Mao, \& Ngo, 2009; Alpkan, Bulut, Gunday, Ulusoy, \& Kilic, 2010; Kaya, Koc, \& Topcu, 2010).

Employees' fairness perceptions regarding their performance appraisals emanate from their interpretations of their varied appraisal experiences (Narcisse \& Harcourt, 2008). Perceptions specifically related to the performance appraisal mechanisms are very critical since the outcomes of performance appraisal mechanisms are used for making decisions about promotion, distribution of pay and rewards, transfer and termination of contract, career 
planning, and goal setting (Boswell \& Boudreau, 2000; Pettijohn, Pettijohn, \& Taylor, 2000; Swiercz et al., 1993). If this process and its results are perceived just by the employees, this creates a helpful climate for positive work-related attitudes towards their organization. Otherwise, employees' expectations regarding training, development, advancement, promotions, and salary progression are not met, thereby lead them not to envisage their future in the organization (Jawahar, 2006; Nurse, 2005). Therefore, individual impact of any employee characteristic that can decrease the level of commitment may be mitigated if the justice perceptions are high. Thus, one can conclude that individual impact of any factor or employee characteristic that can increase the level of turnover intention may be mitigated if the justice perceptions are high. This moderator role of justice perceptions on the employee attitudes and behaviors has been already confirmed by recent empirical studies (e.g. Chien et al., 2010; Choi, 2008; Thompson \& Heron, 2005). Similarly, Haar and Spell (2009) have already tested and confirmed the effects of the interaction between distributive justice and job autonomy- a sense of autonomy and ability to use discretion over how someone does their job, on satisfaction and turnover intentions.

The level of fairness embedded in the performance evaluation system is most probably perceived by the employees that related decision-making procedures are fairly rational and transparent. Even high independents may feel that effectively designed fair appraisal procedures do not limit but guarantee their independence from especially rater biases, misinterpretations, and managerial pressures.

Beyond the fairness of the procedures, what matters for the employees in the appraisal processes is the fairness of the results, i.e. the outcomes distributed. Employees want to be evaluated with objective criteria and rewarded fairly. They wish to receive what they deserve. In the case of high independents, the results of their intrapreneurial undertakings and efforts are very critical since they prefer to be financially independent and take and manage their own risks. If their performance is fairly rewarded to compensate the value of their efforts, they may feel satisfied and committed to the present organization and think that there is no need to look for new career opportunities outside. On the other hand, if the employee believes that the distribution of the rewards is not fair, he or she realizes that there is no need to stay and try again. Furthermore, high independents may believe that synergy between the autonomous intrapreneur and the fair distribution of results within the same organization may create a safer and more satisfying future than the risky results of individual venturing via a new spin off. Figure 1 illustrates the proposed model.

\section{Research Hypotheses}

The following hypotheses guided the study.

$\mathbf{H}_{1}$ : There is a positive relationship between need for independence and turnover intentions.

$\mathbf{H}_{2}$ : There is a negative relationship between need for independence and organizational commitment.

$\mathbf{H}_{3}$ : Perceived justice moderates the relationship between need for independence and turnover intention, in such a way that high levels of justice perceptions will lessen the strength of positive relationship between need for independence and turnover intentions. 
$\mathbf{H}_{4}$ : Perceived justice moderates the relationship between need for independence and affective commitment, in such a way that high levels of justice perceptions will lessen the strength of negative relationship between need for independence and organizational commitment.

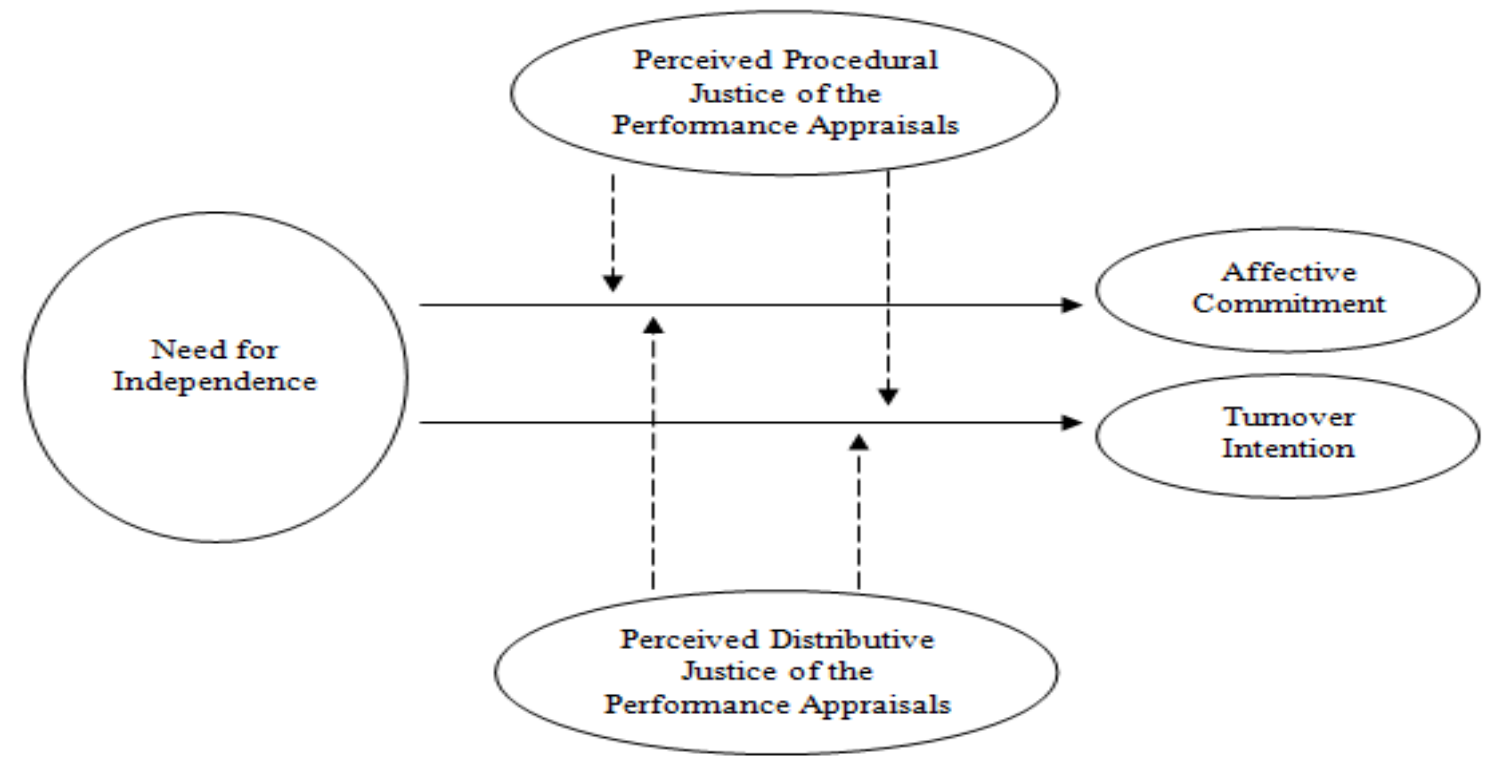

Figure 1. Proposed model

\section{Method}

Considering the specific turnover problem in the high-tech firms, data for our empirical study was collected from the white-collar employees of three high-tech firms, namely a multinational telecom vendor company, an information technology company, and a pharmaceuticals company in Istanbul, Turkey. We randomly chose those companies among the ones that formally and regularly appraise employee performance. One hundred five white-collar employees agreed to participate in our study. The sample was comprised of 68 percent men and 32 percent women; mean age was 30 (standard deviation was 4.46); average tenure of participants was 4.44 (standard deviation was 3.48) years; almost all of them were university graduates. No personal data was collected except the above demographic information.

Data was acquired via a structured questionnaire. All measurements included in the questionnaire were originally developed in English and translated into Turkish via the backtranslation technique, in which each questionnaire was translated from English to Turkish and then back translated from Turkish to English by a different person to see whether it still had the same meaning. A cover letter was also provided to explain the purpose of the survey and to note that participation was voluntary as all participants were assured of confidentiality of the responded questionnaire. Respondents were asked to return the completed questionnaires directly to the research assistant using the envelopes provided to ensure their anonymity. A total of 195 questionnaires constituted the final sample for analysis.

Items used in our questionnaire form to measure the variables were gathered from wellestablished scales that were previously tested and validated in the relevant literature. We asked, 
on a 5-point Likert scale, the level of agreement of the respondents to the items in form of statements about their organizational settings.

Need for independence was measured by a 6-item scale developed and tested by Hisrich and Brush (1985, cited in Hisrich, Peters, \& Shepherd, 2005). Sample items include "I prefer to be independent while I am making important decisions" and "I prefer to be the boss of my own business". Alpha reliability of need for independence is 0.72 .

Procedural justice and distributive justices were measured as reflecting the justice perceptions of the performance appraisal system in the relevant organization. Procedural justice was measured by a 4-item scale and distributive justice was measured by a 4-item scale adapted from the scale developed and tested by Tang and Sarsfield-Baldwin's (1996) study. A sample item from procedural justice scale is "During the performance appraisal process, decisions are made with the participation of employees", and a sample item from distributive justice scale is "Considering the amount of effort that I have put forth, the opportunities and rewards this organization provides me are fair". Alpha reliability of procedural justice is 0.85 , and alpha reliability of distributive justice is 0.96 .

Affective commitment was measured by a 7-item scale adapted from the scale developed and tested by Allen and Meyer (1990). Sample items include "I feel emotionally attached to this organization" and "I really feel that any problems faced by this organization are also my problems". Alpha reliability of affective commitment is 0.93 .

Turnover intentions were measured by 2 items adapted from the scale developed and tested by Cammann, Fichman, Jenkins and Klesh (1983). A sample item is "I often think about quitting my job". Alpha reliability of affective commitment is 0.91 .

\section{Results}

All scales were submitted to exploratory factor analyses with varimax rotation to form the constructs of the study in the Turkish context (using a cut-off point of eigenvalue $=1$ ). Factor analysis produced a five-factor solution as anticipated, namely need for independence, procedural justice perceptions, distributive justice perceptions, organizational commitment, and turnover intention, with a total variance of $77.45 \%$. Factor loadings of items varied from 0.59 to 0.86 . All items loaded on their original factors. Factor loadings and reliability scores are shown in Table 1.

Cronbach's alpha $(\alpha)$ reliability scores of all the factors are all above 0.70 - ranging from 0.72 to 0.96 . This indicates that internal consistency levels of our variables are sufficiently reliable (Nunnally \& Berstein, 1994).

Table 2 shows one-to-one associations among the variables. Considering the means of the variables, all seem moderate ranging between about 3 to 3.5, on a scale from 1 to 5 , except turnover intentions $(\mathrm{m}=2.29)$. Considering the correlations among the variables, affective commitment and turnover intentions are found to be negatively correlated, whereas need for independence is linked negatively to affective commitment and positively related to turnover intentions. Justice perceptions are linked positively to affective commitment and negatively to turnover intentions as expected. Moreover, need for independence and justice perceptions are not significantly correlated. 
Table 1

Factor Analysis and Reliabilities

\begin{tabular}{|c|c|c|c|c|c|}
\hline Items & $\begin{array}{l}\text { Need for } \\
\text { Independence }\end{array}$ & $\begin{array}{c}\text { Affective } \\
\text { Commitment }\end{array}$ & $\begin{array}{l}\text { Distributive } \\
\text { Justice }\end{array}$ & $\begin{array}{l}\text { Procedural } \\
\text { Justice }\end{array}$ & $\begin{array}{l}\text { Turnover } \\
\text { Intention }\end{array}$ \\
\hline NFI - Item 1 & 0.76 & & & & \\
\hline NFI - Item 2 & 0.75 & & & & \\
\hline NFI - Item 3 & 0.72 & & & & \\
\hline NFI - Item 4 & 0.56 & & & & \\
\hline NFI - Item 5 & 0.56 & & & & \\
\hline NFI - Item 6 & 0.51 & & & & \\
\hline $\mathrm{AC}-$ Item 1 & & 0.83 & & & \\
\hline $\mathrm{AC}-$ Item 2 & & 0.83 & & & \\
\hline $\mathrm{AC}-$ Item 3 & & 0.82 & & & \\
\hline $\mathrm{AC}-$ Item 4 & & 0.80 & & & \\
\hline $\mathrm{AC}-$ Item 5 & & 0.74 & & & \\
\hline $\mathrm{AC}-$ Item 6 & & 0.73 & & & \\
\hline $\mathrm{AC}-$ Item 7 & & 0.59 & & & \\
\hline DJ - Item 1 & & & 0.86 & & \\
\hline DJ - Item 2 & & & 0.85 & & \\
\hline DJ - Item 3 & & & 0.84 & & \\
\hline DJ - Item 4 & & & 0.83 & & \\
\hline $\mathrm{PJ}$ - Item 1 & & & & 0.82 & \\
\hline PJ - Item 2 & & & & 0.77 & \\
\hline $\mathrm{PJ}$ - Item 3 & & & & 0.74 & \\
\hline PJ - Item 4 & & & & 0.69 & \\
\hline $\mathrm{TI}$ - Item 1 & & & & & -0.84 \\
\hline TI - Item 2 & & & & & -0.81 \\
\hline Reliability & 0.72 & 0.93 & 0.96 & 0.85 & 0.91 \\
\hline
\end{tabular}

According to our hypotheses, distributive and procedural justice perceptions were proposed to have moderator roles in the relationship between the independent variable, i.e. need for independence and the dependent variables, namely affective commitment and turnover intentions. To test our moderating hypotheses, we used interaction terms of justice perceptions and need for independence which were not found to be correlated to each other. Meanwhile, moderating relationships between the variables were analyzed without centering their means since collinearity statistics showed that all tolerances were more than 0.20 and all the variance inflation factors were less than 10 (O'Brien, 2007). This meant that there was not any serious problem of multicollinearity.

Table 2

Correlations among the Variables

\begin{tabular}{cccccccc}
\hline Variables & Mean & SD & NFI & TI & AC & PJ & DJ \\
\hline NFI & 3.48 & 0.65 & 1 & & & & \\
TI & 2.29 & 1.03 & $0.19^{* *}$ & 1 & & & \\
AC & 3.53 & 0.87 & $-0.18^{*}$ & $-0.60^{* *}$ & 1 & & \\
PJ & 3.52 & 0.91 & -0.02 & $-0.47^{* *}$ & $0.48^{* *}$ & 1 & 1 \\
DJ & 3.03 & 1.07 & -0.10 & $-0.49^{* *}$ & $0.53^{* *}$ & $0.64^{* *}$ & 1
\end{tabular}

NFI: Need for Independence, TI: Turnover Intentions, AC: Affective Commitment, PJ: Procedural Justice, DJ: Distributive Justice

* Pearson Correlation is significant at the 0.05 level (2-tailed).

** Pearson Correlation is significant at the 0.01 level (2-tailed). 
To test our hypotheses, multiple regression analyses (see Table 3) were conducted, where the dimensions of need for independence and justice perceptions were the independent variables and turnover intentions was the dependent variable in steps 1 and 2, and affective commitment was the dependent variable in steps 3 and 4 (see Table 3). The interaction terms (Need for Independence * Procedural Justice) and (Need for Independence * Distributive Justice) were entered into the equations in the second steps of each regression.

Table 3

Results of the Regression Analyses

\begin{tabular}{|c|c|c|c|c|}
\hline \multirow[b]{3}{*}{ Independent Variables } & \multicolumn{4}{|c|}{ Dependent Variables } \\
\hline & \multicolumn{2}{|c|}{ Turnover Intentions } & \multicolumn{2}{|c|}{ Affective Commitment } \\
\hline & Step 1 & Step 2 & Step 3 & Step 4 \\
\hline NFI & $.150^{*}$ & & $-.138 *$ & \\
\hline PJ & $-.266^{* *}$ & & $.244 * *$ & \\
\hline DJ & $-.306^{* *}$ & & $.359^{* *}$ & \\
\hline NFI * PJ & & $-.273^{* *}$ & & $.286^{* *}$ \\
\hline NFI * DJ & & $-.368^{* *}$ & & $.426^{* *}$ \\
\hline adjusted $\mathrm{R}^{2}$ & .29 & .31 & .32 & .37 \\
\hline $\mathrm{F}$ & $27.231 * *$ & $30.010^{* *}$ & $31.372 * *$ & $42.876^{* *}$ \\
\hline$* \mathrm{p}<.05 ; * * \mathrm{p}<.01$ & & & & \\
\hline
\end{tabular}

First, the need for independence has been found to exert a positive effect on turnover intentions. Then, the interaction terms between the need for independence and justice perceptions have been found to be statistically significant and to change the nature of the relationship between the need for independence and turnover intentions. Findings revealed that the positive significant relationship between the need for independence and turnover intentions turns to an insignificant relationship with the moderator role of justice perceptions (i.e. for both procedural and distributive justice perceptions). Under the existence of high justice perceptions, positive link from need for independence to turnover intentions became insignificant and turnover intentions tends to reduce. Figure 2 and 3 also present the interaction effects between the need for independence and justice perceptions on turnover intentions. Thus, our hypothesis 1 proposing a positive relationship between the need for independence and turnover intentions and hypothesis 3 stating that perceived justice moderates the relationship between the need for independence and turnover intention, high levels of justice perceptions which will lessen the strength of positive relationship between need for independence and turnover intentions, were fully supported.

Figure 2 shows the interaction between the need for independence and procedural justice on turnover intentions. 


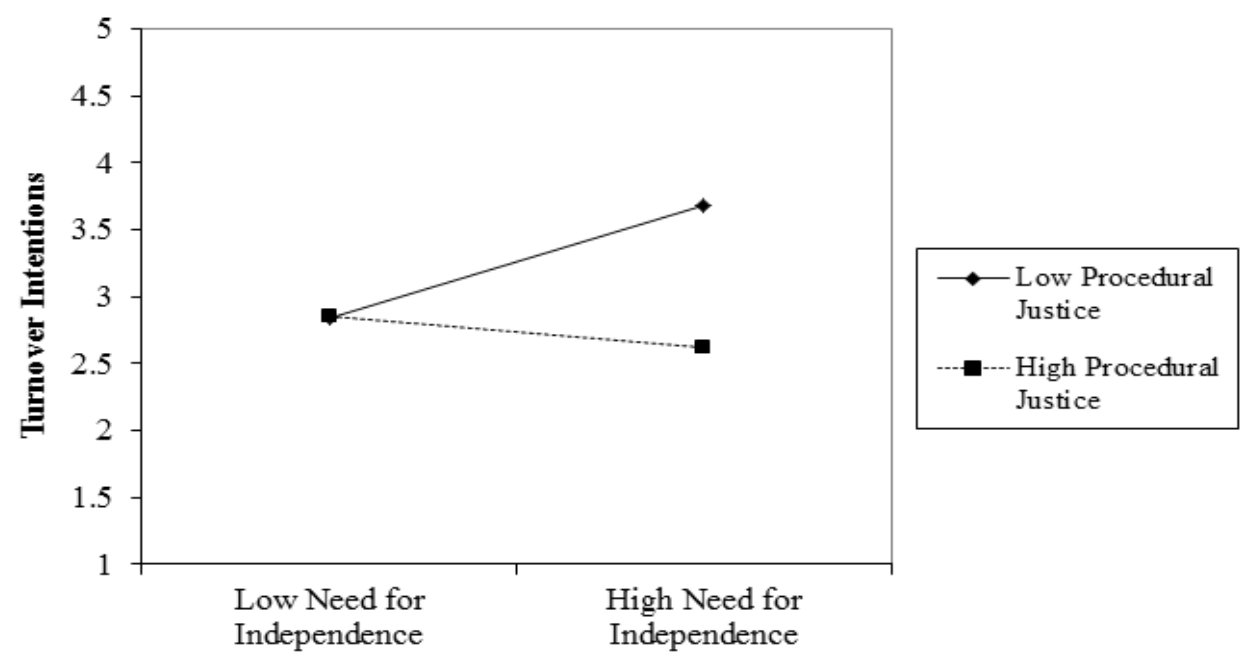

Figure 2. Interaction between the need for independence and procedural justice on turnover intentions

Figure 3 presents the interaction between the need for independence and distributive justice on turnover intentions.

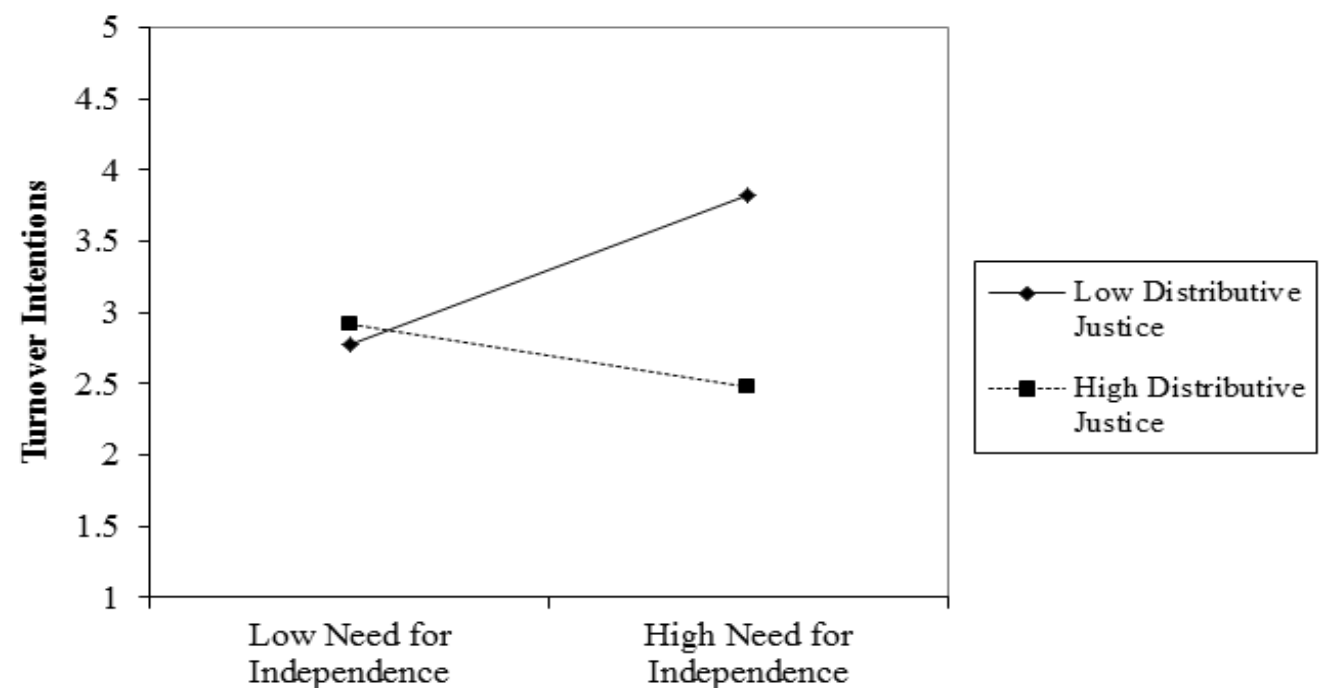

Figure 3. Interaction between the need for independence and distributive justice on turnover intentions

Second, the need for independence has been found to exert a negative influence on affective commitment. Then, the interaction terms between the need for independence and justice perceptions have been found to be statistically significant and to change the nature of the relationship between need for independence and affective commitment. Findings revealed that the negative significant relationship between the need for independence and affective commitment turns to an insignificant relationship with the moderator role of justice perceptions (i.e. for both procedural and distributive justice perceptions). Under the existence of high justice perceptions, negative link from the need for independence to affective commitment became insignificant and affective commitment tends to increase. Figure 4 and 5 depict the interaction effects between the need for independence and justice perceptions on affective commitment. Thus, our hypothesis 2 proposing a negative relationship between the need for 
independence and organizational commitment and hypothesis 4 stating that perceived justice moderates the relationship between the need for independence and affective commitment, high levels of justice perceptions will lessen the strength of negative relationship between need for independence and organizational commitment, were fully supported.

Figure 4 displays the interaction between the need for independence and procedural justice on affective commitment.

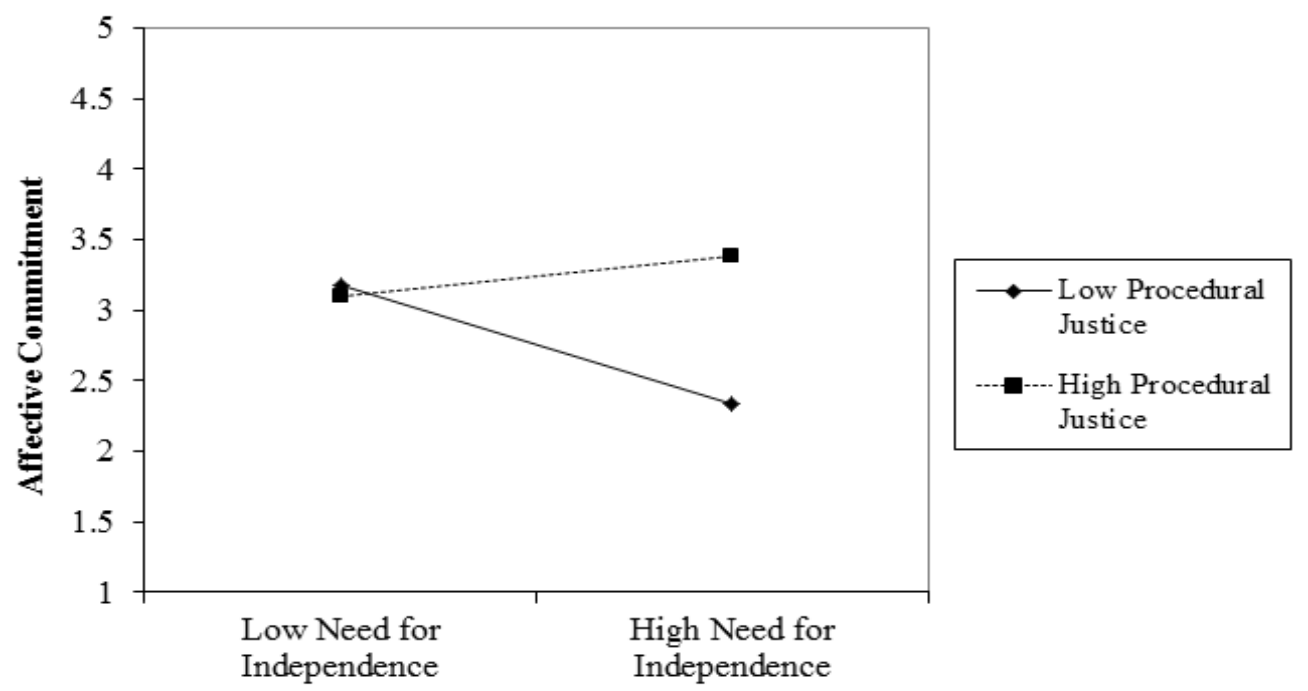

Figure 4. Interaction between the need for independence and procedural justice on affective commitment

Figure 5 shows the interaction between the need for independence and distributive justice on affective commitment.

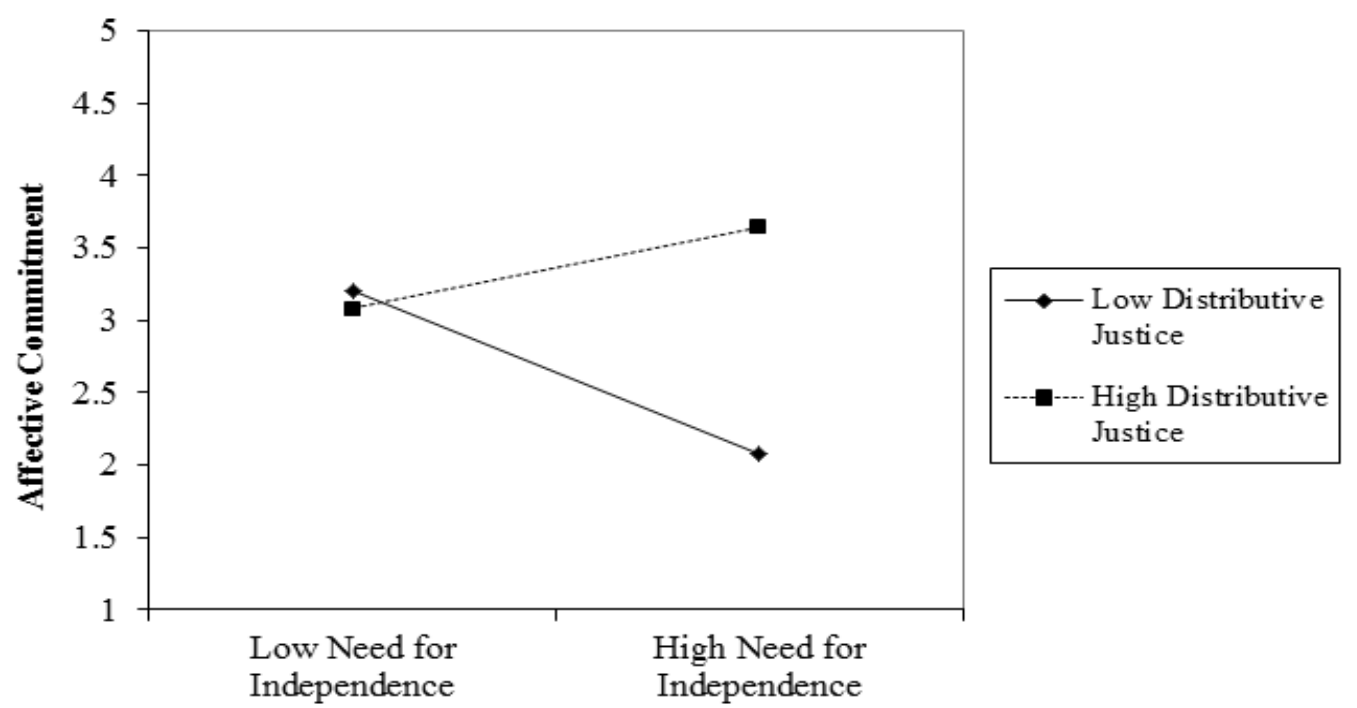

Figure 5. Interaction between the need for independence and distributive justice on affective commitment

\section{Discussion}

Our research question about uncovering the moderating effects of justice perceptions in the relationship between the need for independence, organizational commitment, and turnover 
intentions has been worked out by collecting data via a questionnaire study and by testing hypotheses via regression analyses.

As expected, the need for independence has been found to exert negative effects on affective commitment and positive effects on turnover intentions. This finding supports the idea that universal theories also apply to the Turkish context. Justice perceptions about performance appraisals have been found to play significant moderating roles as hypothesized by our actual study. Findings can be interpretable in such a way that the negative relationship of the need for independence with affective commitment can be converted to a positive effect with the aid of strong procedural justice perceptions. Similarly, the positive relationship of the need for independence with turnover intentions can be changed to a negative effect with the aid of strong procedural justice perceptions. These findings underline the importance of justice perceptions, since they not only lead to positive attitudes and behaviors, but also mitigate the effects of the individual characteristic such as need for independence. Furthermore, strong perceptions of distributive justice yield the same moderator effects but with stronger effect sizes. This can be explained with employees' greater sensitivity for tangible outcomes rather than the details of the bureaucratic procedures.

Considering the aforementioned findings, if management desires to increase organizational commitment and decrease turnover intentions of the employees, it should pay attention to the expectations and characteristics of employees. Employees' personality characteristics should be taken into consideration in recruitment, selection, placement, and other decisions. The congruence between individual characteristics and organizational systems play a very important role in shaping employees attitudes and behaviors toward their workplace. Sensitivities, perceptions, and attitudes of those employees with higher needs for independence and other entrepreneurial characteristics should be known.

Entrepreneurial human capital, a valuable source of competitive advantage, is difficult to be developed, retained, and replaced. In this concern, positive justice perceptions are very instrumental since employees are highly sensitive to the treatment they receive. Sensitivities about the human resource management practices, and specifically performance appraisal policies and their results are very critical. If any, technically effective but misunderstood procedures should be explained and justified by the managers to convince the employees about their effectiveness and fairness. The appraisal system should not be defended as absolutely perfect, but it should be presented as fair. Politeness and transparency are also interpreted by the employees as indicators of fairness. As a result of performance appraisal, employees must feel that they receive not less than what they deserve in terms of increases in salaries, bonuses, fringe benefits, training opportunities, and promotion.

Underestimation of employee characteristics, sensitivities, and attitudes may be very costly. As for the employees with entrepreneurial feelings, judgment of performance appraisal systems as unfair combined with the need for independence may easily cause frustration and detachment. Especially, in the high-tech industries, employee replacement costs are much higher. Transfer attempts of the competitor firms may accelerate this detachment process. Even if turnover intention does not end with quitting the organization, reluctantly staying employees' commitment, motivation, and performance will reduce. 


\section{Conclusion}

Justice seems to be one of the most important strategic resources of companies to attract and retain human capital. Besides, the need for independence which is one of the most important drivers of entrepreneurship contributes to the development of this human capital on the one hand and to the difficulty of retaining it on the other hand. According to the past literature, perception of organizational justice has a positive influence on the employees' judgments about psychological contract fulfillment (Chen, 2010). Performance evaluation procedures and especially results interpreted as unfair may destroy this psychological contract between the firm and the human capital. In order not to let this valuable resource be lost, establishment of a participative, ethical, and intrapreneurial working climate is very instrumental. This can divert the intrapreneurs' sensitivity and challenging characteristics to emotional attachment. Justice perceptions and especially distributive justice perception without reducing the need for independence improves the effect of the latter on organizational commitment and intention to quit. In brief, justice makes possible the effective co-existence of seemingly conflicting features and attitudes in such a working climate where both organizational decentralization and emotional attachment flourish together.

In our empirical study on white-collar high-tech employees, we had also some limitations; the recovery of them may open new avenues for further studies. For instance, in this study, only the need for independence as an entrepreneurial characteristic, and affective commitment and turnover intentions as work-related attitudes have been taken into consideration. In a more comprehensive model, other characteristics and attitudes such as internal locus of control, need for achievement, risk taking propensity, tolerance of ambiguity, interactional justice, trust, continuance commitment, normative commitment, and individual performance ratings might be included in future studies. A longitudinal study can also be conducted to uncover long-term causal relations among variables. Furthermore, the sampling frame may be enlarged to cover more industries (low-tech, service, and others) to compare the results.

To our best knowledge, this was the first empirical research that studied the moderating effect of perceived justice of performance appraisals in the relationship between need for independence, organizational commitment, and turnover intentions. Further research in this area is needed to tie entrepreneurial characteristics with human resource management practices.

\section{References}

Adams, J. S. (1965). Inequity in social exchange. In L. Berkowitz (Eds.), Advances in Experimental Social Psychology (pp. 267-299). New York: Academic Press.

Alexander, S., \& Ruderman, M. (1987). The role of procedural and distributive justice in organizational behavior. Social Justice Research, 1(2), 177-198.

Allen, N. J., \& Meyer, J. P. (1990). The Measurement and antecedents of affective, continuance and normative commitment to the organization. Journal of Occupational Psychology, 63(1), 1-18.

Alpkan, L., Bulut, C., Gunday, G., Ulusoy, G., \& Kilic, K. (2010). Organizational support for intrapreneurship and its interaction with human capital to enhance innovative performance. Management Decision, 48(5), 732-755.

Alpkan, L., Keskin, H., \& Zehir, C. (2002). Girişimcilik hisleriyle girişimcilik potansiyeli arasındaki ilişki: Gebze ve civarındaki girişimciler uzerine bir saha araştırması. 21. Yüzyılda KOBİler Sempozyumu, Doğu Akdeniz Üniversitesi, Cyprus.

Boswell, W. R., \& Boudreau, J. W. (2000). Employee satisfaction with performance appraisals and appraisers: The role of perceived appraisal use. Human Resource Development Quarterly, 11(3), 283-299. 
Bulut, Ç., \& Alpkan, L. (2006). Behavioral consequences of an entrepreneurial climate within large organizations: An integrative proposed model. South East European Journal of Economics \& Business, 1(2), 64-70.

Çalışır, F., Gümüşsoy, C. A., \& Iskin, I. (2011). Factors affecting intention to quit among IT professionals in Turkey. Personnel Review, 40(4), 514-533.

Cammann, C., Fichman, M., Jenkins, D., \& Klesh, J. R. (1983). The Michigan organizational assessment questionnaire: Assessing the attitudes and perceptions of organizational members. In S. E. Seashore, E. E. Lawler, P. H. Mirvis, \& C. Cammann (Eds.), Assessing organizational change: A guide to methods, measures, and practices (pp. 71-138). New York: John Wiley and Sons.

Chen, H. F. (2010). The relationships of organizational justice, social exchange, psychological contract, and expatriate adjustment: An example of Taiwanese business expatriates. The International Journal of Human Resource Management, 21(7), 1090-1107.

Chien, M. S., Lawler, J. S., \& Uen, J. F. (2010). Performance-based pay, procedural justice and job performance for R\&D professionals: Evidence from the Taiwanese high-tech sector. The International Journal of Human Resource Management, 21(12), 2234-2248

Choi, J. P. (2008). Event justice perceptions and employees' reactions: Perceptions of social entity justice as a moderator. Journal of Applied Psychology, 93(3), 513-528.

Cromie, S. (2000). Assessing entrepreneurial inclinations: Some approaches and empirical evidence. European Journal of Work \& Organizational Psychology, 9(1), 7-30.

Elci, M., \& Alpkan, L. (2009). The impact of perceived organizational ethical climate on work satisfaction. Journal of Business Ethics, 84(3), 297-311.

Elci, M, Şener, I., \& Alpkan, L. (2011). The impact of morality and religiosity of employees on their hardworking behavior. Osmania Journal of Social Sciences, 24, 1367-1377.

Erdoğan, B. (2002). Antecedents and consequences of justice perceptions in performance appraisals. Human Resource Management Review, 12, 555-578.

Ertürk, A. \& Vurgun, L. (2015). Retention of IT professionals: Examining the influence of empowerment, social exchange and trust. Journal of Business Research, 68(1), 34-46.

Erdil, O., Alpkan, L. H., \& Biber, L. (2004). İnsan kaynakları uygulamaları ile Örgütsel performans arasındaki İlişkileri araştırmaya yönelik bir İnceleme. Dokuz Eylül Üniversitesi İktisadi ve İdari Bilimler Fakültesi Dergisi, 19(2), 101-122.

Eren, E., Alpkan, L., \& Ergün, E. (2003). Kültürel boyutlar olarak işletmelerde içsel bütünleşme ve dişsal odaklanma düzeylerinin performansa etkileri. Doğuş Üniversitesi Dergisi, 4(1), 55-70.

Fletcher, C., \& Williams, R. (1996). Performance management, job satisfaction and organizational commitment. British Journal of Management, 7(2), 169-179.

Flint, D. H. (1999). The role of organizational justice in multi-source performance appraisal: Theory-based applications and directions for research. Human Resource Management Review, 9(1), 1-20.

Folger, R., \& Konovsky, M. A. (1989). Effects of procedural and distributive justice on reactions to pay raise decisions. Academy of Management Journal, 32(1), 115-130.

Giles, W.F., Findley, H.M., \& Feild, H. S. (1997). Procedural fairness in performance appraisal: Beyond the review session. Journal of Business \& Psychology, 11(4), 493-506.

Grund, C., \& Sliwka, D. (2009). The anatomy of performance appraisals in Germany. The International Journal of Human Resource Management, 20(10), 2049-2065.

Haar, J. M., \& Spell, C. S. (2009). How does distributive justice affect work attitudes? The moderating effects of autonomy. The International Journal of Human Resource Management, 20(8), 1827-1842.

Hisrich, R. D., \& Peters, M. P. (1996). Entrepreneurship: Starting, developing and managing a new enterprise. Homewood, IL: Irwin.

Hisrich, R. D., Peters, M. P., \& Shepherd, D. A. (2005). Entrepreneurship. New York: McGraw-Hill.

Jawahar, I. M. (2006). Correlates of satisfaction with performance appraisal feedback. Journal of Labor Research, 27(2), $213-$ 236.

Kaya, N., Koc, E., \& Topcu, D. (2010). An exploratory analysis of the influence of human resource management activities and organizational climate on job satisfaction in Turkish banks. The International Journal of Human Resource Management, 21(11), 2031-2051.

Kırmizı, A. \& Deniz, O. (2009). The organizational commitment of IT professionals in private banks. Paper presented at European and Mediterranean Conference on Information Systems (EMCIS2009), Crowne Plaza Hotel, Izmir. 
Konovsky, M. A., Folger, R., \& Cropanzano, R. (1987). Relative effects of procedural and distributive justice on employee attitudes. Representative Research in Social Psychology, 17(1), 15-24.

Levy, P. E., \& Williams, J. R. (1998). The role of perceived system knowledge in predicting appraisal reactions, job satisfaction, and organizational commitment. Journal of Organizational Behavior, 19(1), 53-65.

Loi, R., Hang-Yue, N., \& Foley, S. (2006). Linking employees' justice perceptions to organizational commitment and intention to leave: The mediating role of perceived organizational support. Journal of Occupational \& Organizational Psychology, $79(1), 101-120$.

Loi, R., Mao, Y., \& Ngo, H. Y. (2009). Linking leader-member exchange and employee work outcomes: The mediating role of organizational social and economic exchange. Management \& Organization Review, 5(3), 401-422.

Manville, C. (2008). Justice perceptions and organizational commitment: Would contingent and permanent workers be different? Relations Industrielles, 63(3), 529-554.

McFarlin, D. B., \& Sweeney, P. D. (1992). Distributive and procedural justice as predictors of satisfaction with personal and organizational outcomes. Academy of Management Journal, 35(3), 626-637.

Meyer, J. P., \& Allen, N. J. (1991). A three-component conceptualization of organizational commitment. Human Resource Management Review, 1(1), 61-89.

Narcisse, S., \& Harcourt, M. (2008). Employee fairness perceptions of performance appraisal: A Saint Lucian case study. The International Journal of Human Resource Management, 19(6), 1152-1169.

Nunnally, J. C., \& Bernstein, I. H. (1994). Psychometric Theory. New York: McGraw-Hill.

Nurse, L. (2005). Performance appraisal, employee development and organizational justice: Exploring the linkages. The International Journal of Human Resource Management, 16(7), 1176-1194.

O’Brien, R. M. (2007). A caution regarding rules of thumb for variance inflation factors. Quality \& Quantity, 41(5), 673-690.

Orpen, C. (1985). The effects of need for achievement and need for independence on the relationship between perceived job attributes and managerial satisfaction and performance. International Journal of Psychology, 20(2), 207-219.

Pettijohn, C. E., Pettijohn, L. S., \& Taylor, A. J. (2000). Research note: An exploratory analysis of salesperson perceptions of the criteria used in performance appraisals, job satisfaction, and organizational commitment. Journal of Personal Selling \& Sales Management, 20(2), 77-80.

Poon, J. M. L. (2004). Effects of performance appraisal politics on job satisfaction and turnover intention. Personnel Review, $33(3), 322-334$

Ruiz-Moreno, A., Garcia-Morales, V. J., \& Llorens-Montes F. J. (2008). The moderating effect of organizational slack on the relation between perceptions of support for innovation and organizational climate. Personnel Review, 37(5), 509-525.

Simard, G., Doucet, O., \& Bernard, S. (2005). HRM practices and employee commitment: The role of justice. Relations Industrielles, 60(2), 296-319.

Suazo, M. M. (2009). The mediating role of psychological contract violation on the relations between psychological contract breach and work-related attitudes and behavior. Journal of Managerial Psychology, 24(1), 136-160.

Steensma, H., \& Visser, E. (2007). Procedural justice and supervisors' personal power bases: Effects on employees' perceptions of performance appraisal sessions, commitment, and motivation. Journal of Collective Negotiations, 31(2), 101118.

Steers, R. M., \& Braunstein, D. N. (1976). A behaviorally-based measure of manifest needs in work settings. Journal of Vocational Behavior, 9(2), 251-266.

Swiercz, P., Icenogle, M., Bryan, N., \& Renn, R. (1993). Do perceptions of performance appraisal fairness predict employee attitudes and performance? In D. P. Moore (Eds.), Proceedings of the academy of management (pp. 304-308). Atlanta: Academy of Management.

Tang, T. L. P., \& Sarsfield-Baldwin, L. J. (1996). Distributive and procedural justice as related to satisfaction and commitment. SAM Advanced Management Journal, 61(3), 25-31.

Tett, R. P., \& Meyer, J. P. (1993). Job satisfaction, organizational commitment, turnover intention, and turnover: Path analyses based on meta-analytic findings. Personnel Psychology, 46(2), 259-293.

Thompson, M., \& Heron, P. (2005). The difference a manager can make: Organizational justice and knowledge worker commitment. The International Journal of Human Resource Management, 16(3), 383-404.

Vandenberghe, C., \& Bentein, K. (2009). A closer look at the relationship between affective commitment to supervisors and organizations and turnover. Journal of Occupational \& Organizational Psychology, 82(2), 331-348.

Von Hagel Jr, W. J., \& Miller, L. (2011). Precipitating events leading to voluntary employee turnover among information technology professionals. Journal of Leadership Studies, 5(2), 14-33. 